\title{
Radioactivity of waste materials coming from the largest power plants in Poland
}

\author{
Aneta Łukaszek-Chmielewska ${ }^{1}$, Martin Girard ${ }^{1}$, Barbara Piotrowska $^{2}$, \\ Karol Wojtkowski ${ }^{2, *}$, Krzysztof Isajenko ${ }^{2}$, Olga Stawarz ${ }^{2}$, and Robert Godlewski ${ }^{3}$ \\ ${ }^{1}$ The Main School of Fire Service, ul. Słowackiego 52/54, 01-629 Warszawa, Poland \\ ${ }^{2}$ Central Laboratory for Radiological Protection, Department of Dosimetry, ul. Konwaliowa 7, \\ 03-194 Warszawa, Poland \\ ${ }^{3}$ Warsaw University of Technology, Faculty of Physics, ul. Koszykowa 75, 00-662 Warszawa, Poland
}

\begin{abstract}
The Central Laboratory of Radiological Protection together with 30 other laboratories in Poland is involved in the analysis of radioactivity among indirect products of combustion (ashes and slags) coming from polish power plants and thermal power station. Systematic studies are conducted on the concentrations of natural radioactive isotopes in waste materials obtained from the power industry, and their results are recorded in a database. This database is supervised by the Central Laboratory for Radiological Protection. The database already contains 46300 by now and the oldest results come from the eighties. In this article the results of studies on radioactive concentration of natural radioisotopes ${ }^{40} \mathrm{~K},{ }^{226} \mathrm{Ra}$ and ${ }^{228} \mathrm{Th}$ in waste materials coming from the largest power plants in our country are presented. Furthermore an analysis was carried out on the possibility to use the selected waste materials (ashes and slags) in housing construction, road construction and in public facilities buildings, considering the values of activity indexes $f_{l}$ and $f_{2}$.
\end{abstract}

\section{Introduction}

The largest power plants active in Poland are: Bełchatów (5354 MW), Kozienice (2193 MW), Turów (2106 MW), Połaniec (1800 MW), Rybnik (1775 MW), Jaworzno III (1535 MW), Opole (1492 MW), Dolna Odra (1362 MW) and Laziska (1155 MW) [1].

The main task of those power plants is the production of electric and thermal energy through the combustion of hard coal or lignite.

As a result of the coal combustion, energetic waste called indirect products of combustion (UPS) are produced such as: slags, fly ashes, ash-slag mixtures, microspheres, etc. About 24 million tons of such waste is produced annually [2]. Despite the fact, that for years we have been seeking renewable sources of energy, forecasts aren't optimistic for the coming years, as they predict a coal consumption reaching around 10560 million tons in 2030. If we take into account, that $60 \%$ of this coal is dedicated to the production of electric

\footnotetext{
* Corresponding author: karol_wojtkowski@go2.pl
} 
energy, it is estimated that there will be an increase in the amount of UPS to approximately 950 million tons annually [3].

In the eighties of $20^{\text {th }}$ century, the level of economic use was only $30 \%$, while it reaches now $70 \%$, but it isn't identical for all groups of waste. In the case of ash-slag mixtures the level of economic use is around $50 \%$, for slags it's over $88 \%$ and for fly ashes it reaches even $96 \%$ [4]. Therefore, at the present time, energy waste is not treated as troublesome production waste anymore, but as a valuable raw material used in various industries such as construction, mining or agriculture.

One of the main industries using ashes is the cement industry. Ashes act as aggregates and binders in the production of cellular concrete and is partly a replacement to cement. In addition, ashes are used as an active additive - ground together with Portland clinker, it affects the change of usable characteristics of the binder and leads to the formation of pozzolanic cement. It should also be mentioned that ashes increase the weight of cement, and improve also the resistance of concrete to aggressive factors, which prevents their corrosion and reduces their shrinkage. Siliceous fly ashes introduced in the amount of $20 \%$ of the cement mass results in a significant improvement of concrete resistance to cracking [5]. Fly ashes are currently used as an additive to multicomponent cements, drilling cements and conventional, high-value and self-compacting cements [6-12].

Ashes and slags are also used for road embankments, soil stabilization and to improve the base and sub-base layers $[2,5,13]$.

In addition to the construction industry, fly ashes are also used in mining. They are used to fill underground cavities by injecting them under the pressure of $0.05-0.2 \mathrm{MPa}$. Additionally, ashes are used to "shield" coal heaps from fire by covering them with a sealing layer $[2,14]$.

Furthermore, fly ashes are used in agriculture, where it plays a role of calcium and magnesium fertilizer. Fly ashes obtained from lignite accelerate the alkalization process, as well as increase the absorption capacity and absorbency to water of the soil and also reduced its density $[2,15]$.

In the plastics and paint industry, fly ashes play the role of fillers, which significantly reduce the costs of plastic production, improve their mechanical properties and reduced the flammability of the materials obtained [2].

Bearing in mind the widespread use of indirect products of combustion in various branches of the industry, the question of where UPS are safe materials for people arises. It must be emphasized, that ash as a waste material with mineral origins contains in its composition natural radioactive elements such as: potassium ${ }^{40} \mathrm{~K}$, radium ${ }^{226} \mathrm{Ra}$ and thorium ${ }^{228} \mathrm{Th}$. In order to take a decision to allow the use of building materials in selected types of constructions, measurements of their radioactivity level are necessary.

The basic legal act defining the requirements for raw material and construction materials used in various types of construction is the regulation from the Council of Ministers of January 2, 2007 (Dz. U. nr 4/2007, pos. 29) [16].

This regulation classifies the raw materials and building materials considering their use in various types of construction by determining two parameters:

1. Activity index $f_{l}$, which takes into account the content in natural radioactive isotopes, is defined by the equation:

$$
f_{1}=\frac{S_{K}}{3000}+\frac{S_{R a}}{300}+\frac{S_{T h}}{200}
$$

where: $S_{K}, S_{R a}, S_{T h}$ are the radioactive concentrations of the following natural elements: potassium $\left({ }^{40} \mathrm{~K}\right)$, radium $\left({ }^{226} \mathrm{Ra}\right)$ and thorium $\left({ }^{228} \mathrm{Th}\right)$, in $\mathrm{Bq} / \mathrm{kg}$. 
The value of activity index $f_{l}$ gives information on the exposure of the human body to gamma radiation emitted by natural radionuclides.

2. Activity index $f_{2}$, which determines the content of radium $\left({ }^{226} \mathrm{Ra}\right)$, being the parent isotope of radon. Therefore, the value of this index determines the degree exposure to alpha radiation coming from radon (it is the index of lung epithelium exposure to alpha radiation emitted by radon decay products inhaled with air by humans):

$$
f_{2}=S_{R a}
$$

\section{Method of measurement}

The studies of radioactivity of waste materials were performed using the MAZAR type and AZAR type analyzers combined with $\mathrm{NaI}(\mathrm{Tl})$ scintillation probe. These analyzers work in three measuring ranges and let determine the radioactive concentrations of natural elements such as: ${ }^{40} \mathrm{~K},{ }^{226} \mathrm{Ra}$ and ${ }^{228} \mathrm{Th}$. Based on the determined concentrations, the activity indexes $f_{1}$ and $f_{2}$ can be calculated. The measuring ranges of the analyzers are contained in the following energy ranges: range for ${ }^{40} \mathrm{~K}$ - from $1.26 \mathrm{MeV}$ to $1.65 \mathrm{MeV}$, range for ${ }^{226} \mathrm{Ra}$ - from $1.65 \mathrm{MeV}$ to $2.30 \mathrm{MeV}$ and range for ${ }^{228} \mathrm{Th}$ - from $2.30 \mathrm{MeV}$ to $2.85 \mathrm{MeV}$.

Calibration of the detector efficiency is based on measurements of three volume calibration references: ${ }^{40} \mathrm{~K},{ }^{226} \mathrm{Ra}$ and ${ }^{228} \mathrm{Th}$ and measurement of the matrix reference (background measurement). The geometry of the reference sources are Marinelli beakers with a capacity of $1.5 \mathrm{dm}^{3}$. The density of the reference sources equals $1.6 \mathrm{~g} / \mathrm{cm}^{3}$, however the density of the measured samples of raw and building materials is in the range from $0.6 \mathrm{~g} / \mathrm{cm}^{3}$ to $2.0 \mathrm{~g} / \mathrm{cm}^{3}$.

In order to minimize the external background, the detector is placed in a protective casing made of lead with a wall thickness of $50 \mathrm{~mm}$. Shredded and sieved through a sieve with a mesh thickness of $2 \mathrm{~mm}$, the samples are packed into Marinelli beakers with a capacity of $1.5 \mathrm{dm}^{3}$ and then sealed tightly. Samples are studied only once, after minimum 5 days, when the radioactive equilibrium has been reached between radium ${ }^{226} \mathrm{Ra}$ and bismuth ${ }^{214} \mathrm{Bi}$ as well as between thorium ${ }^{228} \mathrm{Th}$ and thallium ${ }^{208} \mathrm{Tl}$ [16]. Measurements were made in series of multiple repetitions (from 5 to 32) [17].

\section{Results of radioactivity studies}

In tables 1 and 2, we present the mean values and ranges of radioactive concentration in ash and slag samples coming from the largest power plants in Poland during the years 1980-2015 for the following radioactive natural isotopes: potassium $\left({ }^{40} \mathrm{~K}\right)$, radium $\left({ }^{226} \mathrm{Ra}\right)$ and thorium $\left({ }^{228} \mathrm{Th}\right)$.

Mean values of radioactive concentrations of natural isotopes ${ }^{40} \mathrm{~K},{ }^{226} \mathrm{Ra}$ and ${ }^{228} \mathrm{Th}$ for ashes for the whole Poland are: $703 \mathrm{~Bq} / \mathrm{kg}, 120 \mathrm{~Bq} / \mathrm{kg}$ and $91 \mathrm{~Bq} / \mathrm{kg}$, respectively [18]. Therefore, in the case of potassium isotope the mean values of concentration in Poland were not exceeded for the following power plants: Jaworzno III, Turów and Bełchatów. However when comparing the mean values of radium concentration for Poland with the studied power plants, it can be concluded that lower values than the mean value of ${ }^{226} \mathrm{Ra}$ were only obtained in the Laziska power plant. Considering the mean value of thorium isotope concentration, which is $91 \mathrm{~Bq} / \mathrm{kg}$ for Poland, it can be stated, that it wasn't exceeded only in the Bełchatów power plant.

The highest mean values of radioactive concentration of natural isotopes were obtained in ash samples coming from Rybnik for ${ }^{40} \mathrm{~K}$, Turów for ${ }^{226} \mathrm{Ra}$ and Połaniec for ${ }^{228} \mathrm{Th}$. 
Table 1. Radioactive concentrations of ${ }^{40} \mathrm{~K},{ }^{226} \mathrm{Ra}$ and ${ }^{228} \mathrm{Th}$ in ash samples coming from the largest power plants in Poland.

\begin{tabular}{|c|c|c|c|c|c|c|}
\hline \multirow{2}{*}{ Power plant } & \multicolumn{6}{|c|}{ Radioactive concentration [Bq/kg] } \\
\cline { 2 - 8 } & \multicolumn{2}{|c|}{${ }^{\mathbf{4 0} \mathbf{K}}$} & \multicolumn{2}{c|}{$\mathbf{2 2 6}^{\mathbf{2 2}}$} & \multicolumn{2}{c|}{${ }^{\mathbf{2 2 8}} \mathbf{T h}$} \\
\cline { 2 - 7 } & Mean & Range & Mean & Range & Mean & Range \\
\hline Laziska & 788 & $594-954$ & 107 & $16.9-183.3$ & 103 & $7.2-128.8$ \\
\hline Dolna Odra & 834 & $692-916$ & 131 & $11.0-178.9$ & 98.3 & $92-116.8$ \\
\hline Opole & 780 & $158-1053$ & 136 & $7.8-237.5$ & 113 & $5.5-141.5$ \\
\hline Jaworzno III & 693 & $242-869$ & 140 & $23.0-182.3$ & 9.2 & $40.0-130.0$ \\
\hline Rybnik & 904 & $830-1043$ & 128 & $98.0-154.6$ & 113 & $104-119$ \\
\hline Połaniec & 767 & $470-911$ & 153 & $79.0-203.4$ & 117 & $72.0-137.0$ \\
\hline Turów & 450 & $378-529$ & 202 & $185-216$ & 106 & $95.0-115.0$ \\
\hline Kozienice & 799 & $468-1024$ & 127 & $89.5-189.0$ & 90.9 & $65.7-130.0$ \\
\hline Bełchatów & 74 & $70-80$ & 150 & $83.0-209.0$ & 53.3 & $37.0-71.0$ \\
\hline
\end{tabular}

The lowest mean values of radioactive concentration of ${ }^{40} \mathrm{~K}$ and ${ }^{228} \mathrm{Th}$ were obtained for ash samples coming from the Bełchatów power plant, and the lowest value of radioactive concentration of ${ }^{226} \mathrm{Ra}$ was noticed in ashes from the Laziska power plant [19].

Table 2. Radioactive concentrations of ${ }^{40} \mathrm{~K},{ }^{226} \mathrm{Ra}$ and ${ }^{228} \mathrm{Th}$ slag samples coming from the largest power plants in Poland.

\begin{tabular}{|c|c|c|c|c|c|c|}
\hline \multirow{2}{*}{ Power plant } & \multicolumn{6}{|c|}{ Radioactive concentration [Bq/kg] } \\
\cline { 2 - 8 } & \multicolumn{2}{|c|}{${ }^{\mathbf{4 0} K}$} & \multicolumn{2}{|c|}{${ }^{\mathbf{2 2 6}} \mathbf{R a}$} & \multicolumn{2}{c|}{${ }^{\mathbf{2 2 8}} \mathbf{T h}$} \\
\cline { 2 - 8 } & Mean & Range & Mean & Range & Mean & Range \\
\hline Laziska & 560 & $118-807$ & 87.1 & $32.0-130.0$ & 78.8 & $16.0-107.0$ \\
\hline Dolna Odra & 861 & $680-1260$ & 89.9 & $52.1-113.0$ & 94.0 & $76.1-161.0$ \\
\hline Opole & 552 & $339-939$ & 115 & $32.3-183.1$ & 82.7 & $43.2-105.9$ \\
\hline Jaworzno III & 505 & $191-878$ & 88.3 & $38.0-156.9$ & 73.8 & $20.4-144.4$ \\
\hline Rybnik & 743 & $669-828$ & 117 & $104-124$ & 87.4 & $74.1-101.1$ \\
\hline Połaniec & 763 & $592-883$ & 101 & $78.0-117.0$ & 91.1 & $65.0-106.0$ \\
\hline Turów & 385 & $161-695$ & 86.1 & $37.0-127.0$ & 60.4 & $34.0-98.0$ \\
\hline Kozienice & 706 & $542-806$ & 115 & $77.7-148.2$ & 79.7 & $56.9-92.0$ \\
\hline Bełchatów & 52 & $39-64$ & 161 & $102-219$ & 59.0 & $41.0-77.0$ \\
\hline
\end{tabular}

The highest mean values of radioactive concentrations of ${ }^{40} \mathrm{~K}$ and ${ }^{228} \mathrm{Th}$ were obtained for slag samples coming from the Dolna Odra power plant. The highest mean value of radioactive concentration of ${ }^{226} \mathrm{Ra}$ was obtained for slags from the Bełchatów power plant.

The lowest mean values of radioactive concentrations of ${ }^{40} \mathrm{~K}$ and ${ }^{228} \mathrm{Th}$ were obtained for slags delivered by the Bełchatów power plant, while the lowest mean value of radioactive concentration of ${ }^{226} \mathrm{Ra}$ was obtained for the Turów power plant. 


\section{Assessment of possibilities to use ashes and slags in building construction}

In order to assess the possibility to use waste materials in a given type of construction, the activity indexes $f_{l}$ and $f_{2}$, must be calculated and then the studied materials must be classified in accordance to the guidelines contained in the regulation of the Council of Ministers of January 2, 2007.

Mean values of activity index $f_{l}$ for ash samples coming from the largest power plants in Poland are presented in Figure 1 . The red line shows the limit of activity index $f_{l}=1.2$ determined for construction intended for the stay of people and livestock.

The values of the activity index $f_{l}$ describing the exposure of body to gamma radiation coming from natural radionuclide, are contained in the range from 0.79 to 1.36 . Most of them exceed the accepted values from the regulation [16] concerning raw materials used in building intended for human stays and livestock by more than $20 \%$.

The lowest mean value of activity index $f_{l}=0.79$ was obtained for ashes coming from the Bełchatów power plant and was about $34 \%$ lower than the limit of activity index $\left(f_{l}=1.2\right)$. However the highest mean values of activity index $f_{l}=1.36$ was obtained in the ashes delivered by the Turów power plant and was about $13.3 \%$ higher than the limit value. For four power plants (Opole, Rybnik, Połaniec and Turów) the mean value of activity index $f_{l}$ was noticed to be higher than the limit value determined for the housing construction of $6.6 \%, 7.5 \%, 12.5 \%$ and $13.3 \%$, respectively. For comparison, the mean value of activity index in Poland is 1.08 [19].

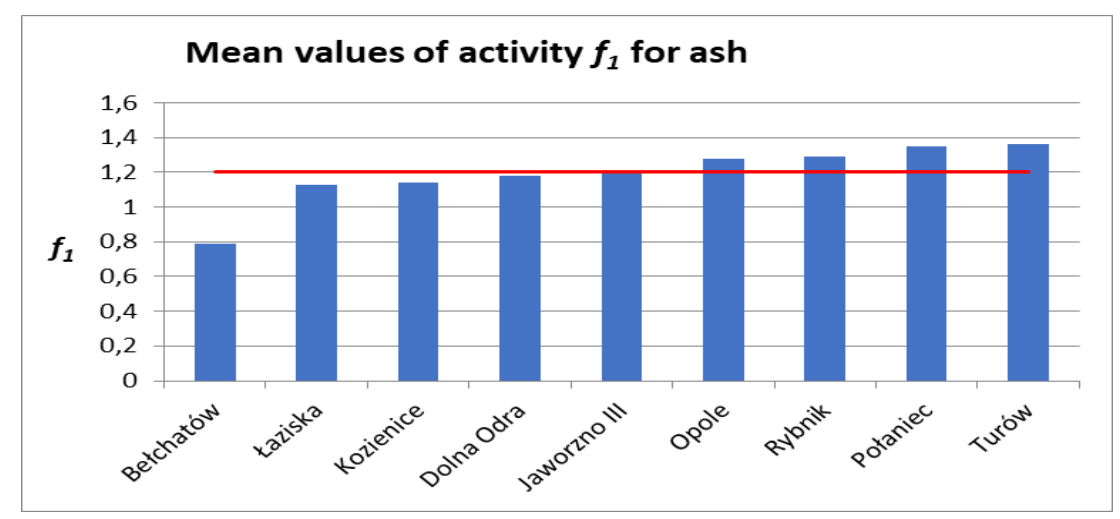

Fig. 1. Mean value for the activity index $f_{1}$ for ash samples coming from the largest power plants in Poland.

Mean values of activity index $f_{2}$ for ashes coming from the largest power plants in Poland are presented in Figure 2. The red line shows the limit of activity index $f_{2}=240 \mathrm{~Bq} / \mathrm{kg}$ determined for housing construction.

Mean values of the activity index $f_{2}$ for ashes ranges from $107 \mathrm{~Bq} / \mathrm{kg}$ (Laziska power plant) to $202 \mathrm{~Bq} / \mathrm{kg}$ (Turów power plant). For all the ash samples, the mean value of activity index $f_{2}$ obtained are below the limit determined for the housing construction (Fig. 3). The lowest mean value of activity index $f_{2}$ was obtained for the ash samples coming from Łaziska power plant and was about 55.5\% lower than the limit value of activity index $f_{2}=240 \mathrm{~Bq} / \mathrm{kg}$. Mean values of the activity index $f_{l}$ for slag samples coming from the largest power plants in Poland are presented in Figure 3. The red line shows the 
limit for activity index $f_{l}=1.2$ determined for construction intended for human stays and livestock.

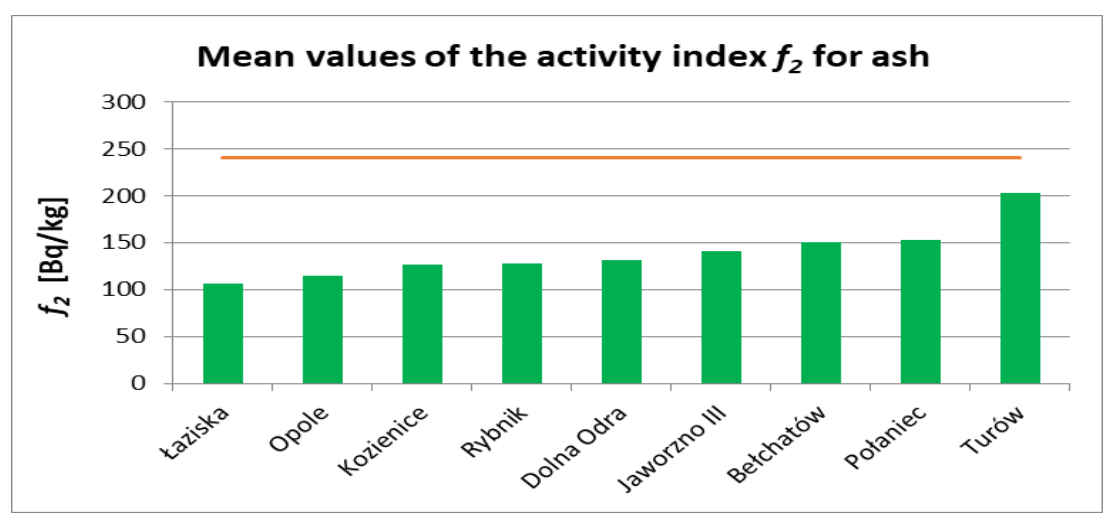

Fig. 2. Mean values of the activity index $\mathrm{f}_{2}$ for ash samples coming from the largest power plants in Poland.

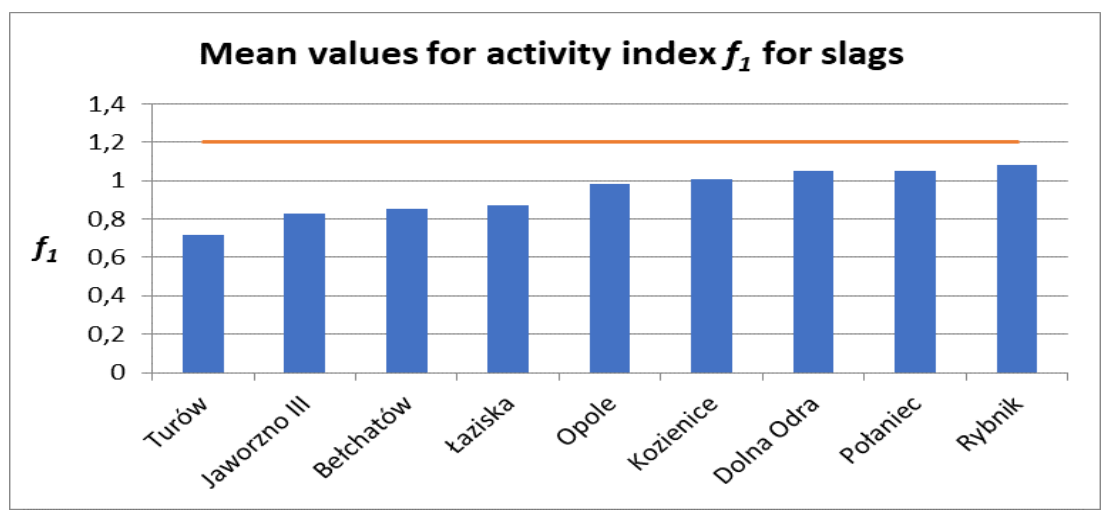

Fig. 3. Mean values of activity index $f_{1}$ for slag samples coming from the largest power plants in Poland.

The values of activity index $f_{l}$ are contained in the range from 0.72 to 1.08 and do not exceed by more than $20 \%$ the values accepted in the regulation [16] for raw materials used to produce building materials intended to the housing or livestock construction.

The lowest mean value of the activity index $f_{l}$ for the slag samples was obtained for the Turów power plant $\left(f_{l}=0.72\right)$, while the highest mean value of the activity index $f_{l}$ was measured for the Rybnik power plant $\left(f_{l}=1.08\right)$. In the case of slag samples, it can be seen that the limit value of activity index $f_{l}=1.2$ wasn't exceed, therefore waste can be used in the housing construction.

Mean values of activity index $f_{2}$ for slag samples coming from the largest power plants in Poland are presented in Figure 4. The red line shows the limit for activity index $f_{2}=240 \mathrm{~Bq} / \mathrm{kg}$. determined for housing construction.

The range of values of activity index $f_{2}$ for the studied slag samples is between $86.1 \mathrm{~Bq} / \mathrm{kg}$ (Turów power plant) and $161 \mathrm{~Bq} / \mathrm{kg}$ (Bełchatów power plant). As can be seen from the data presented in Fig. 5 , the values of activity index $f_{2}$, giving information about the content in radium in the studied materials, are below the limit value determined for the housing construction. Therefore, in this case as well all the studied samples meet the 
requirements presented in the regulation from the Council of Ministers of January 2, 2007 "on the requirements for the content of natural potassium K-40, radium Ra-226 and thorium Th-228 in raw materials used in buildings intended for human stays and livestock, as well as the content in industrial waste used in construction and control of the content of these isotopes."

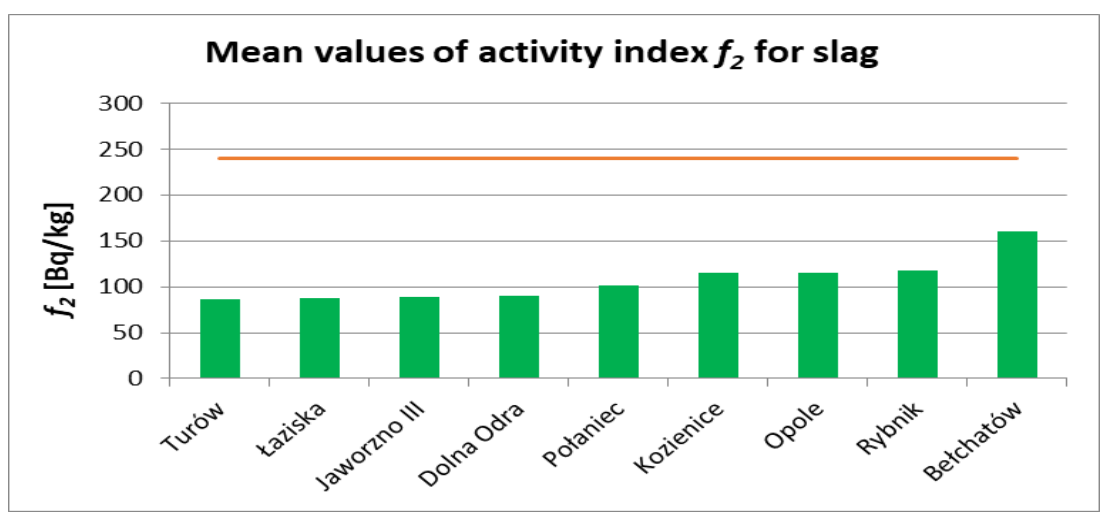

Fig. 4. Mean values of activity index $\mathrm{f}_{2}$ for slag samples coming from the largest power plants in Poland.

\section{Conclusions}

Based on the results of measurements taken in the years 1980 - 2015 on ashes and slags samples, it can be observed that in most of the cases the concentration of potassium was a few times higher than the concentrations of radium and thorium (Tables 1 and 2) [20].

Analyzing the values of all indexes, both the ones giving information about the exposure of human body to gamma radiation emitted by natural radionuclide like ${ }^{40} \mathrm{~K},{ }^{226} \mathrm{Ra}$ and ${ }^{228} \mathrm{Th}$, defined by $f_{l}$, and the ones describing the degree of exposure to alpha radiation coming from radon, defined by $f_{2}$, it can be stated that the slag samples are characterized by much lower values of activity indexes $f_{l}$ and $f_{2}$ comparing to ash samples.

Based on the determined activity indexes $f_{1}$ and $f_{2}$, it can be observed, that all the slag samples meet the requirements described in the regulation of the Council of Ministers of January 2, 2007 and can be used in all types of constructions. In the case of ashes, the limit value of activity index $f_{l}$ for the housing construction was exceeded in most of the samples, but ashes can still be used in other types of constructions.

The lowest mean value of activity index $f_{l}$ was obtained for ashes coming from the Bełchatów power plant. However for the slag samples delivered by the largest power plants in Poland, the lowest radioactive concentrations of natural isotopes was found for the Turów power plant. Analyzing the content of radium defined by the activity index $f_{2}$ in ashes and slag samples, the lowest mean values were observed in Laziska power plants for ashes and in Turów power plant for slags. All mean values of activity index $f_{2}$ are below the limit determined for buildings intended for human stays and livestock.

A permanent control of building materials coming from the industry insures, that the use in construction of combustion waste such as ashes and slags is safe in regard to the radiological effects to humans health. 


\section{References}

1. http://geoland.pl/dodatek/energia-xxv/efektywnosc-konkurencyjnosc-ekologia/ (access: 27.09.2016)

2. G. Borowski, IE 22, 52-62 (2010)

3. J. J. Hycnar, EUROCOALASH weryfikacja popiołów ze spalania węgla (ENP, 2009)

4. K. Galos, A. Uliasz-Bocheńczyk, GSM 1, 21, 23-42 (2005)

5. G. L. Golewski, CWB 2, 106-114 (2015)

6. E. Tkaczewska, J. Małolepszy, CWB 1, 26 (2009)

7. W. Kurdowski, A. Bochenek, CWB 6, 434 (2012)

8. W. Kurdowski, Dodatki mineralne do cementu a trwałość betonu (Mon. 106, WPK, 1990)

9. G. L. Golewski, P. Golewski, T. Sadowski, CMS 62, 75 (2012)

10. Z. Giergiczny, J. Małolepszy, J. Szwabowski, J. Śliwiński, Cementy z dodatkami mineralnymi w technologii betonów nowej generacji (Górażdże Cement, 2002)

11. J. Bensted, J.R. Smith, CWB 1, 17 (2008)

12. J. Filipiak, ROŚ 15, 1153 (2013)

13. J. Kukiełka, Wykorzystanie popiołów lotnych do budowy dróg, E 4, 8-11 (1998)

14. Z. Chrzanowski, Formalno-prawne zasady wykorzystania popiołów do makroniwelacji $i$ rekultywacji wyrobisk (KNT, Rekultywacja terenów zdegradowanych w województwie szczecińskim, Nowe Czarnowo, 1995)

15. Z. Piotrowski, A. Uliasz-Bocheńczyk, GSM 24, 2/1 (2008)

16. Rozporządzenie Rady Ministrów z dnia 2 stycznia 2007 roku w sprawie wymagań dotyczących zawartości naturalnych izotopów promieniotwórczych potasu K-40, radu Ra-226 i toru Th-228 w surowcach i materiałach stosowanych w budynkach przeznaczonych na pobyt ludzi i inwentarza żywego, a także w odpadach przemysłowych stosowanych w budownictwie oraz kontroli zawartości tych izotopów, Dz. U. 4/2007, poz. 29.

17. K. Isajenko, B. Piotrowska, O. Stawarz, Ł. Obigowski, A. Łukaszek-Chmielewska, ZN SGSP 60, 4 (2016)

18. A. Żak, K. Isajenko, B. Piotrowska ${ }_{2}$ M. Kuczbajska, A. Ząbek, T. Szczygielski, Nukl. 55, 3, 387-391 (2008)

19. B. Piotrowska, M. Fujak, K. Isajenko, S. Krawczyńska, BiTP 44, 4, 127-134 (2016)

20. K. Kovler, CBM 29, 158 (2012) 